Geology, Geophysics \& Environment • $2012 \bullet$ Vol. 38 • No. 2 • 189-208

http://dx.doi.org/10.7494/geol.2012.38.2.189

\title{
SALT RESOURCES IN POLAND AT THE BEGINNING OF THE 21ST CENTURY
}

\author{
Stan zasobów soli w Polsce na początku XXI wieku
}

\section{Grzegorz CZAPOWSKI ${ }^{1}$ \& Krzysztof BUKOWSKI $^{2}$}

\author{
${ }^{1}$ Państwowy Instytut Geologiczny-Państwowy Instytut Badawczy; \\ ul. Rakowiecka 4,00-975 Warszawa; e-mail: grzegorz.czapowski@pig.gov.pl \\ ${ }^{2}$ AGH Akademia Górniczo-Hutnicza, Wydziat Geologii, Geofizyki i Ochrony Środowiska; \\ al. A. Mickiewicza 30,30-059 Kraków; e-mail: buk@agh.edu.pl
}

\begin{abstract}
The paper summarized the actual knowledge on resources (anticipated economic and subeconomic ones) of both rock and potash salts estimated in the documented salt deposits in Poland as well as their predicted (prognostic and prospective) resources calculated to the depth of $2 \mathrm{~km}$. The late Permian (Zechstein) rock salts predominated (ca 95\% of anticipated resources and ca. 99.9\% of predicted ones, the Miocene salts are marginal). The most (up to 69\%) of their anticipated resources concentrated in the salt dome deposits but $96.7 \%$ of the prognostic ones - in stratiform deposits. The anticipated rock salt resources could prove over $26 \mathrm{Ka}$ of exploitation (at the current production rate) but the predicted ones $>500$ years assuming that $1 / 10^{6}$ of total resources will be excavated. The anticipated economic resources of Permian potash salts in non-exploited five deposits are $>669 \mathrm{mln} \mathrm{t}$ (mainly $>597 \mathrm{mln} \mathrm{t}$ of polyhalite type in four stratiform deposits) and the predicted ones were estimated at ca. 1.02 bln $\mathrm{t}$.
\end{abstract}

Key words: resources and reserves, rock salt, potash salt, Poland

Treść: W pracy przedstawiono aktualny stan wiedzy o udokumentowanych (bilansowych i pozabilansowych) zasobach soli kamiennej i soli potasowej w Polsce oraz scharakteryzowano ich oszacowane zasoby przewidywane do głębokości $2 \mathrm{~km}$. Dominującą rolę w bilansie zasobowym odgrywają sole kamienne wieku późnopermskiego (ok. 95\% zasobów udokumentowanych i blisko $99.9 \%$ zasobów przewidywanych), udział soli wieku mioceńskiego jest podrzędny. Większość (blisko 69\%) zasobów udokumentowanych kryje się w wysadach solnych, zaś zasobów przewidywanych - w złożach pokładowych (96.7\%). Udokumentowane zasoby soli kamiennej wystarczą na 26000 lat (przy aktualnej wielkości wydobycia), zaś zasoby przewidywane na ponad 500 lat (przy wykorzystaniu $1 / 10^{6}$ części zasobów). Zasoby bilansowe późnopermskich soli potasowo-magnezowych w nieeksploatowanych udokumentowanych pięciu złożach wynoszą ponad $669 \mathrm{mln} \mathrm{t}, \mathrm{z}$ czego większość (cztery złoża, powyżej $597 \mathrm{mln}$ t) stanowią złoża typu polihalitowego. Zasoby przewidywane tych soli oszacowano na blisko $1.02 \mathrm{mld}$ t.

Słowa kluczowe: zasoby, sól kamienna, sól potasowa, Polska 


\section{INTRODUCTION}

Similarly to Germany, Poland is exceptionally rich in salt on the European scale, especially in respect of rock salt. It is due to the huge rock and potash-magnesium salt deposits of the Late Permian (Zechstein), which fill the giant North European Permian Sedimentary Basin occupying nearly $60 \%$ of the Polish territory, with the salt series thickness of nearly $1.4 \mathrm{~km}$ (Czapowski \& Bukowski 2010). The Miocene rock salts, up to 200-300 m thick, occur in the narrow Carpathian Foredeep in southern Poland. The centuries long tradition of shallow salt mining there was finished practically at the end of the XX century, and some of the historical salt mines have transformed into the tourist, landmark, and rest sites.

The Late Permian salts are presently a basic object of salt exploitation and they constitute both current and future salt resources. Almost whole extracted rock salt (more than $3.7 \mathrm{mln} t$ in 2010) (Szuflicki et al. 2011) came from the documented resources located in the domes in the Polish Lowland area and from the stratiform deposits of the Fore-Sudetic Monocline. A number of deposits remains untouched and the intention of this paper was to present estimations of total national rock and potash-magnesium salt resources (currently documented and anticipated ones down to the depth of $2 \mathrm{~km}$ ). Complex geological recognition of these deposits is essential for the planning of their future management, especially when now the salt formations and structures have become desirable geological rock bodies for the underground hydrocarbons storage or hazardous wastes (including radioactive wastes) repository.

\section{CURRENTLY DOCUMENTED SALT RESOURCES IN POLAND}

\section{Rock salt}

Anticipated economic resources of rock salt, documented in 19 deposits (Czapowski \& Bukowski 2010), amounted to 85.3 bln t in 2010 (Szuflicki et al. 2011), including the Miocene salt deposits (three locations: Rybnik-Żary-Orzesze, Siedlec-Moszczenica and Wojnicz) estimated at 4.37 bln t (5.1\% of the total anticipated economic resources), with the Permian salt resources (14 locations) estimated at 80.96 bln t (94.9\% of total resources). Among the Permian salts, the dominant (Fig. 1, Tab. 1) resources are placed in ten locations recognized within seven diapirs (nearly 56 bln $\mathrm{t}$ and $69.1 \%$ of the national resources). The salt deposits from four stratiform locations are estimated at nearly 25 bln t (30.9\% of national resources).

Anticipated subeconomic resources of rock salt amounted to more than $20.6 \mathrm{bln} \mathrm{t}$ in 2010 (op. cit.), with absolute majority of Permian salts (eight deposits) estimated at 20631 bln $\mathrm{t}$ (99.72\% of total subeconomic resources). They are concentrated mainly in salt diapirs (four locations; nearly $13 \mathrm{bln} \mathrm{t}, 62.6 \%$ of total resources), while the resources of the four stratiform deposits are estimated at 7.7 bln $\mathrm{t}$ (37.4\% of total resources) (Fig. 1, Tab. 1). The Miocene rock salts are nominal in this category, and they are estimated at $58.2 \mathrm{mln} \mathrm{t}(0.28 \%$ of total resources) in two locations (Siedlec-Moszczenica and Wieliczka). 


\section{Table (Tabela) 1}

Volume and percent of documented resources related to various types of Permian rock salt deposits in Poland

Udział zasobów poszczególnych typów udokumentowanych złóż soli cechsztyńskich w Polsce

\begin{tabular}{|c|c|c|c|c|}
\hline Deposit type & $\begin{array}{c}\text { Anticipated economic } \\
\text { resources [mln t] }\end{array}$ & $\begin{array}{c}\text { Percent } \\
\text { of total } \\
{[\%]}\end{array}$ & $\begin{array}{c}\text { Anticipated subeconomic } \\
\text { resources } \\
{[\mathrm{mln} \mathrm{t}]}\end{array}$ & $\begin{array}{c}\text { Percent } \\
\text { of total } \\
{[\%]}\end{array}$ \\
\hline Salt dome & $\begin{array}{c}55966.8 \\
\text { (ten deposits) }\end{array}$ & 69.1 & $\begin{array}{c}12951.2 \\
\text { (four deposits) }\end{array}$ & 62.6 \\
\hline Stratiform & $\begin{array}{c}24998.2 \\
\text { (four deposits) }\end{array}$ & 30.9 & $\begin{array}{c}7727.9 \\
\text { (four deposits) }\end{array}$ & 37.4 \\
\hline Total & 80965.0 & 100 & 20643.1 & 100 \\
\hline
\end{tabular}

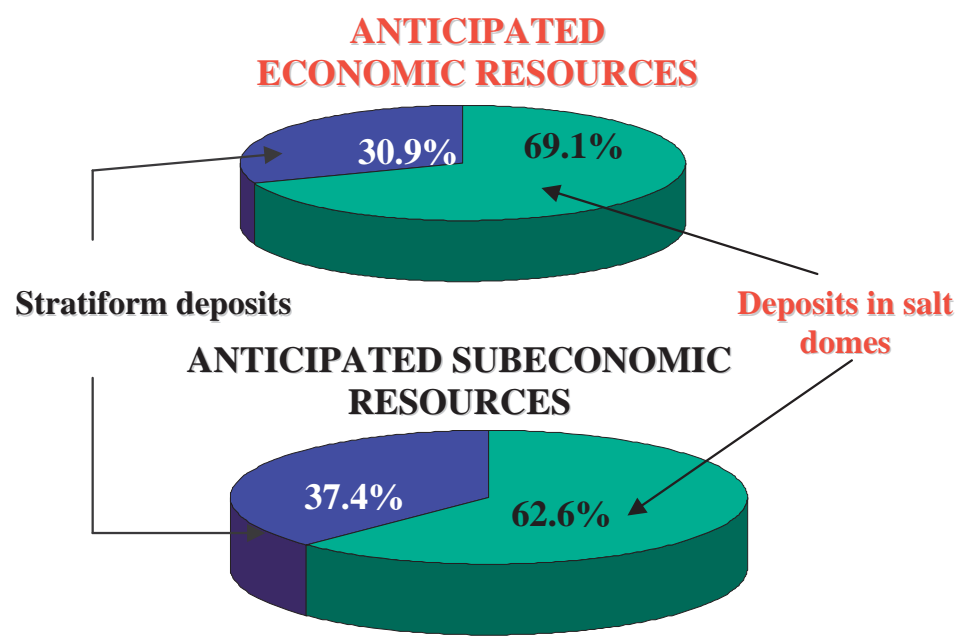

Fig. 1. Resources relations of various types of Permian rock salt deposits in Poland

Fig. 1. Diagram pokazujący proporcje między zasobami różnych typów udokumentowanych złóż permskiej soli kamiennej w Polsce

\section{Potash salt}

Anticipated economic resources of potash-magnesium salts were documented in five locations with amount to $>669 \mathrm{mln} \mathrm{t}$ (Szuflicki et al. 2011), including the dominated sulphate salts (polyhalite) (four deposits, ca. $597 \mathrm{mln} \mathrm{t;} \mathrm{89.2 \%} \mathrm{of} \mathrm{total} \mathrm{resources)} \mathrm{of} \mathrm{the} \mathrm{Bay} \mathrm{of} \mathrm{Puck}$ (Czapowski et al. 2008, Czapowski \& Bukowski 2010) where their deposits are surrounded by stratiform rock salt deposits (Fig. 2). 


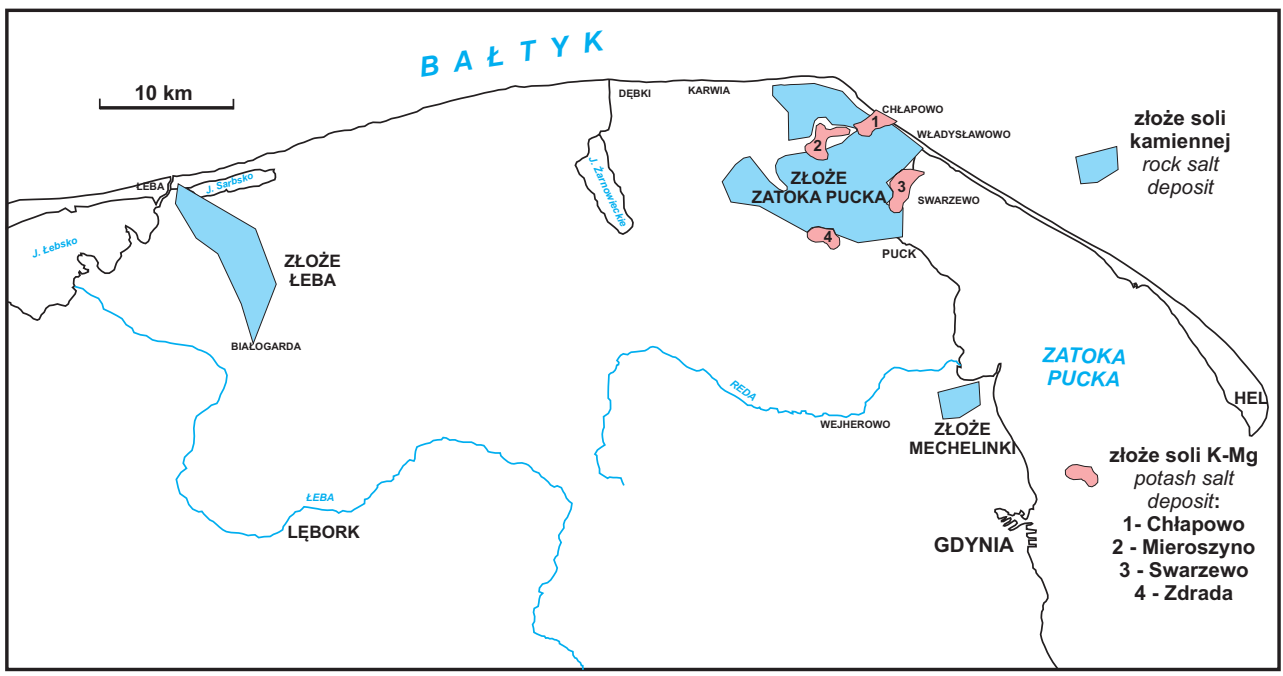

Fig. 2. Distribution of stratiform Permian rock salt and potash deposits at the Puck Bay (after Czapowski et al. 2008)

Fig. 2. Rozmieszczenie pokładowych złóż permskiej soli kamiennej i soli potasowo-magnezowych w rejonie Zatoki Puckiej (wg Czapowski et al. 2008)

The anticipated economic and the subeconomic resources of the Puck Bay (20.6 mln t; $93 \%$ of total resources) (Szuflicki et al. 2011) should be rather included in the prognostic resources owing to a low recognition level (a low documenting category), with the occurrence depth down to $1000 \mathrm{~m}$, lack of management and the changed concept of polyhalite mineralization genesis. These factors could highly affect the resource estimation (Czapowski \& Bukowski 2010, with literature).

Small accumulations of potash salts (anticipated economic resources amounting to $72 \mathrm{mln} \mathrm{t} ; 10.8 \%$ of total resources; subeconomic resources: $1.5 \mathrm{mln} \mathrm{t} ; 7 \%$ of total resources) (Szuflicki et al. 2011) were documented in the Kłodawa salt dome area (Fig. 3). It is necessary to emphasize that those salts are actually not exploited in Poland.

\section{PREDICTED SALT RESOURCES IN POLAND}

The Polish prospective resources of mineral quantities estimated 16 years ago (Bąk \& Przeniosło 1993) have been re-estimated by the Polish Geological Institute-the National Research Institute in 2008-2009, including rock salt and potash-magnesium salts (Fig. 3) (Wołkowicz et al. 2011). New estimations for predicted salt resources were presented (with subdivision to prognostic [ $\mathrm{D}_{1}$ category] and prospective $\left[\mathrm{D}_{2}\right.$ and $\mathrm{E}$ categories] ones) down to $2 \mathrm{~km}$ (this depth has been technically assumed as the maximum depth for location of storage caverns) (Ślizowski et al. 2007). 


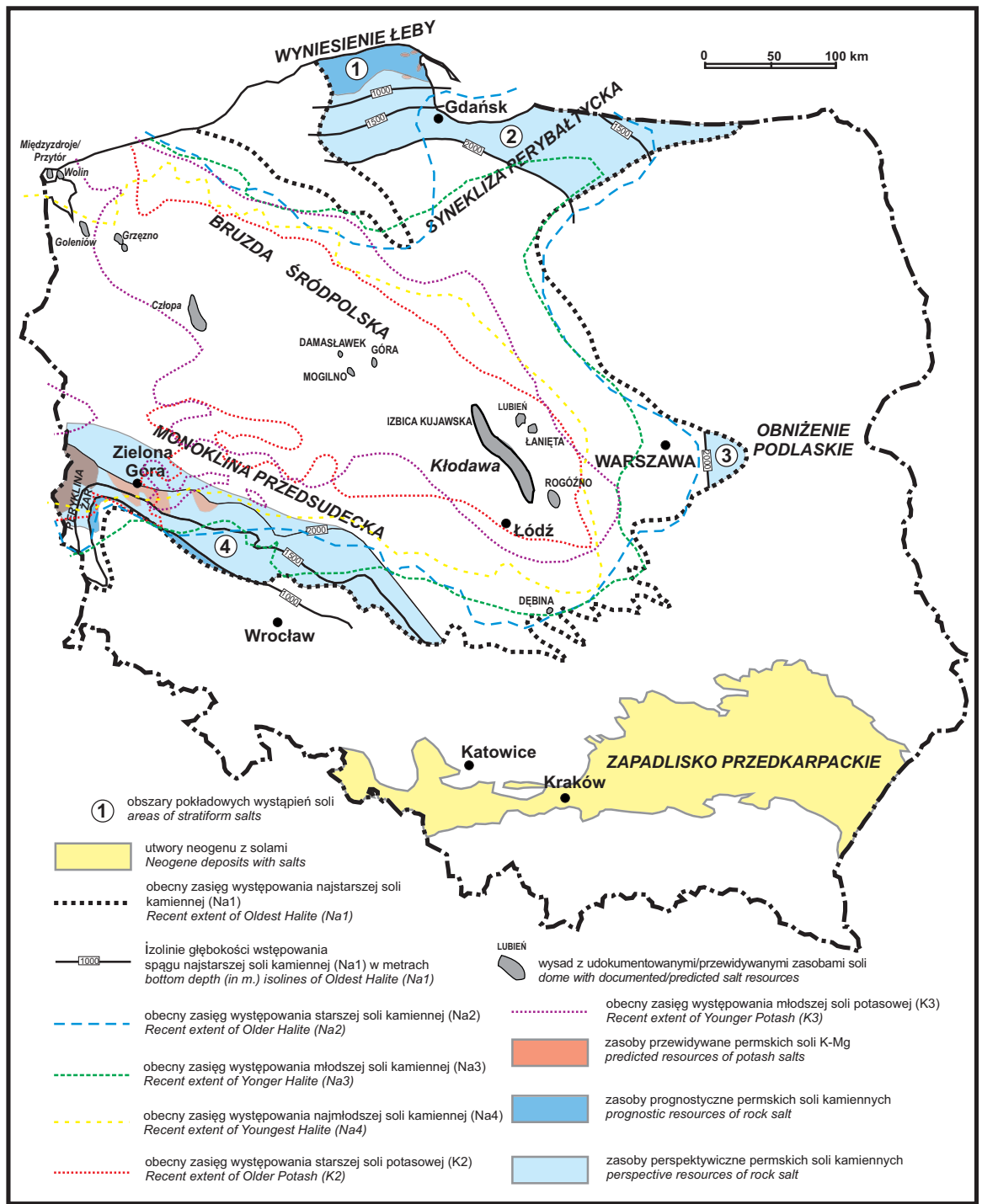

Fig. 3. Distribution of predicted (prognostic and prospective) Zechstein salt resources in Poland (Czapowski \& Bukowski 2011)

Fig. 3. Mapa występowania zasobów przewidywanych permskiej soli kamiennej i soli potasowo-magnezowych w Polsce (Czapowski \& Bukowski 2011)

As it was mentioned above the salt deposits are more and more often used as exceptionally beneficial geological formations for the construction of cavern storage facilities for crude oil, natural gas or other fuels (e.g. currently operating facilities at the deposits of Moglino II 
and Góra) (e.g. Karnkowski and Czapowski 2007), as well as the safe underground disposal facilities for hazardous wastes. So at the resource re-estimation of rock salt deposits, it is necessary to assume the proper geological criteria required for such facilities construction. It was agreed (Ślizowski et al. 2007) that the maximum depth of substances storage in rock salt formations should not exceed $2000 \mathrm{~m}$, with the optimum depth interval of 1200-1400 m for cavern location.

The criteria assumed in the predicted resource estimation (Tab. 2) took into account both new and previous depth requirements for the salt series (Bąk \& Przeniosło 1993) (e.g. the salt series thickness which is different depending on a deposit form and regions, the coefficient of geological structure complication - value 0.3 - in the areas with intensive tectonic rebuilding). The rock salt density was assumed at $2.1 \mathrm{t} / \mathrm{m}^{3}$ and a similar one was attributed for potash-magnesium salts because the total content of main $\mathrm{K}-\mathrm{Mg}$ salt minerals (sylvine, carnallite, polyhalite, and kieserite) reaches max. $25 \%$, commonly it varies from $8 \%$ to $14 \%$. With the specific weight difference from $1.6 \mathrm{~g} / \mathrm{cm}^{3}$ (carnallite) to $2.78 \mathrm{~g} / \mathrm{cm}^{3}$ (polyhalite) and changing proportions of the above mentioned minerals accompanied by halite (except for documented polyhalite resources in sulphate seams e.g. in the Puck Bay area), it is reasonable to assume such specific weight estimations which are close to those of rock salt.

Classifying to the given resource category depended on the unique geological structure of the analyzed area and the parameters of particular deposits. Within the Carpathian Foredeep the areas with rock salts, occurring down to $1500 \mathrm{~m}$, recognized geophysical and by drillings to the degree insufficient to attribute them the category $\mathrm{C}_{2}$, were considered as the prognostic resources, while the resources found at the depth of 1500-2000 m were rather classified as prospective ones (Tab. 2).

Table (Tabela) 2

Criteria for estimation of predicted (prognostic and prospective) rock salt and potash resources in Poland

Kryteria szacowania zasobów prognostycznych i perspektywicznych soli kamiennej i soli potasowo-magnezowych w Polsce

\begin{tabular}{|c|c|c|}
\hline Deposit type & $\begin{array}{c}\text { Seam thickness } \\
{[\mathrm{m}]}\end{array}$ & $\begin{array}{c}\text { Seam depth interval } \\
{[\mathrm{km}]}\end{array}$ \\
\hline \multicolumn{2}{|c|}{ ROCK SALT } \\
\hline $\begin{array}{c}\text { Stratiform deposits from Łeba } \\
\text { Elevation area }\end{array}$ & 35 & $0.1-0.7=$ prospective resource \\
\cline { 2 - 3 } & 35 & $0.7-1.0=$ prospective resource \\
\hline $\begin{array}{c}\text { Stratiform deposits from Peribaltic } \\
\text { Syneclise }\end{array}$ & 5 & $1-2=$ prospective resource \\
\hline $\begin{array}{c}\text { Stratiform deposits from Podlasie } \\
\text { Depression }\end{array}$ & & $1.5-2.0=$ prospective resource \\
\hline
\end{tabular}


Table (Tabela) 2 cont. / cd.

\begin{tabular}{|c|c|c|}
\hline \multirow{2}{*}{$\begin{array}{l}\text { Stratiform deposits from Fore- } \\
\text {-Sudetic Monocline }\end{array}$} & \multirow{2}{*}{50} & $\leq 1.0=$ prognostic resource \\
\hline & & $\leq 2.0=$ prospective resource \\
\hline \multirow{2}{*}{$\begin{array}{l}\text { Stratiform-folded deposits from } \\
\text { Carpathian Foredeep }\end{array}$} & \multirow{2}{*}{$\begin{array}{c}35 \times 0.3 \text { (coefficient } \\
\text { of tectonic } \\
\text { complication) }\end{array}$} & $\leq 1.5=$ prognostic resource \\
\hline & & $1.5-2.0=$ prospective resource \\
\hline \multirow[b]{2}{*}{ Deposits in salt domes } & \multirow{2}{*}{$\begin{array}{l}\text { seam thickness } \\
\times 0.3 \text { (coefficient } \\
\text { of tectonic } \\
\text { complication) }\end{array}$} & $\leq 1.0=$ prognostic resource \\
\hline & & $\leq 2.0=$ prospective resource \\
\hline \multicolumn{3}{|c|}{ POTASH SALTS } \\
\hline \multirow{2}{*}{$\begin{array}{l}\text { Stratiform deposits from Fore- } \\
\text {-Sudetic Monocline }\end{array}$} & \multirow{2}{*}{$\begin{array}{c}5 \times 0.3 \text { (coefficient } \\
\text { of tectonic } \\
\text { complication) }\end{array}$} & $\leq 1.0=$ prognostic resource \\
\hline & & $\begin{array}{c}\leq 2.0=\text { zasoby perspektywiczne } \\
\text { perspective resource }\end{array}$ \\
\hline \multirow{2}{*}{ Deposits in salt domes } & \multirow{2}{*}{$\begin{array}{l}\text { drilled seam } \\
\text { thickness }\end{array}$} & $\leq 1.0=$ prognostic resource \\
\hline & & $\leq 2.0=$ prospective resource \\
\hline
\end{tabular}

However, in the case of rock salt deposits found in the Leba Elevation area, the resources situated at the depth interval of 700-1000 m were included to the prognostic ones. They were classified partly as $\mathrm{C}_{1}$ category and classified as the theoretical resources (Bąk \& Przeniosło 1993), while the adjacent parts located shallower (100-700 m) in a smaller area became presently included into the prospective category (Tab. 3). In the Fore-Sudetic Monocline, salts found at the depth of $1000 \mathrm{~m}$ are classified as prognostic resources, while those situated at the depth of $1-2 \mathrm{~km}$ as the prospective ones. In the Podlasie Lowlands, deep-placed Zechstein rock salts of 1.5-2 km belong to the prospective deposits, while the same resources of the Peri-Baltic Syneclise occurred within a similar depth interval as in the Fore-Sudetic Monocline. For alt domes the assumed depth criterion depends on the individual dome recognition. Usually, the depth of $1000 \mathrm{~m}$ is assumed as the maximum for prognostic resources for non-mined structures but, holding geological documentation and resource estimation. For preliminary recognized objects all the resources down to $2 \mathrm{~km}$ are classified as prospective ones. Similar depth criteria of commented resource categories are assumed, depending on the deposit type, for potash-magnesium salts (Tab. 2).

It is necessary to emphasize that the knowledge of salts distribution, especially of Permian ones, has not changed much in the past 15 years. A number of mined deposits became closed, mainly in the Carpathian Foredeep, while the new deposits were not documented. However, documentary supplements to the exploited resource appeared as well as the changed concepts of some mineralization genesis, suggesting the necessity of re-estimation of the formerly documented resources, e.g. the polyhalite deposits of the Puck Bay area (e.g. Czapowski et al. 2008). For that reason, numerous deposit areas and their estimated resources are still valid, as stated in 1993 (Bąk \& Przeniosło 1993). 


\section{Rock salt}

The Upper Permian (Zechstein) rock salt deposits occur in two forms (Fig. 3):

A. Permian stratiform deposits, mainly on the margins of the former Permian basin, e.g. the Leba Elevation, Peri-Baltic Syneclise, and Fore-Sudetic Monocline with the Żary Pericline.

B. Permian deposits in the salt structures (from salt anticlines, pillows, walls and domes/ diapirs), with the height of up to $7 \mathrm{~km}$, occurring in the area of Mid-Polish Trough where the earliest recognized salt structures are associated with the Kujawy region.

Better recognized but not mined rock salt resources down to $1000 \mathrm{~m}$ (sometimes classified in categories $C_{2}$ and $C_{1}$ ) were included in the prognostic class, while poorly recognized ones (sporadically classified in category $\mathrm{C}_{2}$ ), found at the depth interval of $1-2 \mathrm{~km}$, are mostly included in the prospective class. Selected geological and raw material parameters, as well as the amount of predicted rock salt resources in Poland are listed in tables 3-7.

\section{Permian stratiform deposits}

On the Łeba Elevation the prognostic halite resources of the depth interval of 700-1000 m are found on the area of $1491 \mathrm{~km}^{2}$, reduced by the area of the currently leached Mechelinki deposit (Fig. 3, Tab. 3). The resource amount is over 107 bln t, while the prospective rock salt resources calculated after general regional recognition to the depth of $700 \mathrm{~m}$, are estimated at 65 bln t (Bąk \& Przeniosło 1993). Total predicted salt resources of that area are over $172 \mathrm{bln} t$.

In the Peribaltic Syneclise, the rock salt prospective resources are estimated for the depth interval of 1-2 km, with the average seam thickness of $35 \mathrm{~m}$ (Fig. 3, Tab. 3).

In the north-eastern part of the Syneclise, within the belt from Lidzbark Warmiński to Kościerzyna, the prospective resources of the Oldest Halite (Na1) formation covered the the area of $9900 \mathrm{~km}^{2}$ are estimated at 727.65 billions ton (Bąk \& Przeniosło 1993). Salt seam 35.5-195 m thick was found at the depth interval of 1296-1800 m. Above lying (depth $1350-1710 \mathrm{~m}$ ) the seam of the Older Halite (Na2), 30-72 m thick, occupies a smaller area of $4206 \mathrm{~km}^{2}$ and its prospective resources are estimated at $309.16 \mathrm{bln}$ t. Total prospective resources of both rock salt deposits are estimated at $1036.81 \mathrm{bln} \mathrm{t}$.

East of Warsaw, in the Podlasie Lowlands (Fig. 3, Tab. 3), between Lochów, Dębe, Okuniew and Radzymin, the area of $500 \mathrm{~km}^{2}$ was identified with the rock salt prospective resources (Na1 seam, up to $5 \mathrm{~m}$ thick) estimated at 5 bln t (Bąk \& Przeniosło 1993). Salt was found there at the depth of 1450-1610 m.

In the Fore-Sudetic Monocline area and its westernmost part called the Żary Pericline (Fig. 3, Tab. 3), there are four Zechstein rock salt complexes identified (from Na1 to Na4) of which only two, the Oldest (Na1) Halite and the Younger (Na3) Halite fulfil the assumed criteria of the predicted resource estimation. By now, the resources of two rock salt deposits have been estimated: Kazimierzów in the Sieroszowice mining area and Bytom Odrzański.

The estimated resources $\left(\mathrm{C}_{1}\right.$ category) of Bytom Odrzański deposit (Kozula \& Golczak 1988) were estimated at 8.52 bln $t$ for the Oldest Halite seam and for all the four occurred salt 
seams from $\mathrm{Na} 1$ to Na4) they were estimated at 48.76 bln t. Those resources are classified as the prospective ones, similarly to the estimated Kazimierzów/Sieroszowice deposit, found below the depth of $1000 \mathrm{~m}$.

\section{Table (Tabela) 3}

Selected parameters and predicted (prognostic and prospective) Permian rock salt resources of stratiform occurrences in Poland

Wybrane parametry i zasoby przewidywane (prognostyczne + perspektywiczne) permskiej soli kamiennej $w$ wystapieniach poktadowych w Polsce

\begin{tabular}{|c|c|c|c|c|c|c|c|}
\hline \multirow[b]{2}{*}{ No. } & \multirow{2}{*}{$\begin{array}{l}\text { Name of } \\
\text { salt dome } \\
\& \text { salt } \\
\text { deposit }\end{array}$} & \multirow{2}{*}{$\begin{array}{c}\text { Deposit } \\
\text { area } \\
{\left[\mathrm{km}^{2}\right]}\end{array}$} & \multicolumn{2}{|c|}{ Resources } & \multirow{2}{*}{$\begin{array}{c}\text { Depth } \\
\text { of salt top } \\
{[\mathrm{m}]}\end{array}$} & \multirow{2}{*}{$\begin{array}{c}\text { Salt } \\
\text { thickness } \\
{[\mathrm{m}] \times} \\
\text { tectonic } \\
\text { coefficient }\end{array}$} & \multirow{2}{*}{$\begin{array}{c}\text { Main } \\
\text { component } \\
\text { content } \\
{[\% \mathrm{NaCl}]}\end{array}$} \\
\hline & & & $\begin{array}{l}\text { prognostic } \\
{[\mathrm{mln} \mathrm{t}]}\end{array}$ & $\begin{array}{l}\text { prospective } \\
{[\mathrm{mln} \mathrm{t}]}\end{array}$ & & & \\
\hline \multirow{2}{*}{1} & \multirow{2}{*}{$\begin{array}{c}\text { Łeba } \\
\text { Elevation }\end{array}$} & $1491 * *$ & $107025^{* *}$ & - & $700-1000 *$ & $35^{*}$ & $80.0-99.8$ \\
\hline & & $900 *$ & - & $65000 *$ & $100-700 *$ & $35^{*}$ & b.d. \\
\hline 2 & $\begin{array}{l}\text { Peribaltic } \\
\text { Syneclise }\end{array}$ & $9900 *$ & - & 1036810 & $1000-2000^{*}$ & $35^{*}$ & to $98^{*}$ \\
\hline 3 & $\begin{array}{c}\text { Podlasie } \\
\text { Depression }\end{array}$ & $500 *$ & - & $5000^{*}$ & $1500-2000 *$ & $5^{*}$ & b.d. \\
\hline \multirow{2}{*}{4} & \multirow{2}{*}{$\begin{array}{c}\text { Fore-Sudetic } \\
\text { Monocline }\end{array}$} & $449.4 * * *$ & $44913.7 * * *$ & - & $\leq 1000^{*}$ & $50 *$ & 85-99* \\
\hline & & 6200 & - & 921522 & $1000-2000 *$ & $50 *$ & $82-99$ \\
\hline & Total & 19440.4 & 151938.7 & 2028332.0 & - & - & - \\
\hline
\end{tabular}

* data after Bąk \& Przeniosło 1993,

** data after Bąk \& Przeniosło 1993, without resources of Mechelinki salt deposit,

*** data after Bąk \& Przeniosło1993, without resources of Sieroszowice salt deposit, b.d. - lack of data.

The area of prospective resources found on the Fore-Sudetic Monocline, occupied by the Oldest Halite (Na1) salt complex at the depth of 1-2 km and with its average thickness of $50 \mathrm{~m}$, was estimated at $2927.5 \mathrm{~km}^{2}$, while the resources at $307387.5 \mathrm{mln}$ t. The resources of Younger Halite (Na3) complex were estimated, with the same criteria, at $614135 \mathrm{mln}$ t, and they occupy the area of $5849 \mathrm{~km}^{2}$. Total area of prospective rock salt resources found in both salt complexes in the Fore-Sudetic Monocline was estimated at $6200 \mathrm{~km}^{2}$, while the resources at $921522.5 \mathrm{mln} \mathrm{t}$ (Tab. 3).

\section{Permian deposits in the salt structures}

The prognostic and prospective resources of the nine recognized and documented salt domes (Fig. 4) are presented in table 4 after a previous study (Bąk \& Przeniosło 1993) because of no exploitation and the better recognition of most of them. Only in the Kłodawa, Mogilno and Góra domes, the documented salt deposits are mined. However, an underground 
salt mine placed in the central part of the Kłodawa dome operates down to $750 \mathrm{~m}$. For that reason, the prognostic resources of Kłodawa deposit, established at the depth interval of 1-2 km, practically remain unchanged. Similar assumptions were applied to estimate the prognostic resources of Mogilno and Góra domes at the depth interval of 1-2 km, with solution mining down to $1.4-1.6 \mathrm{~km}$.

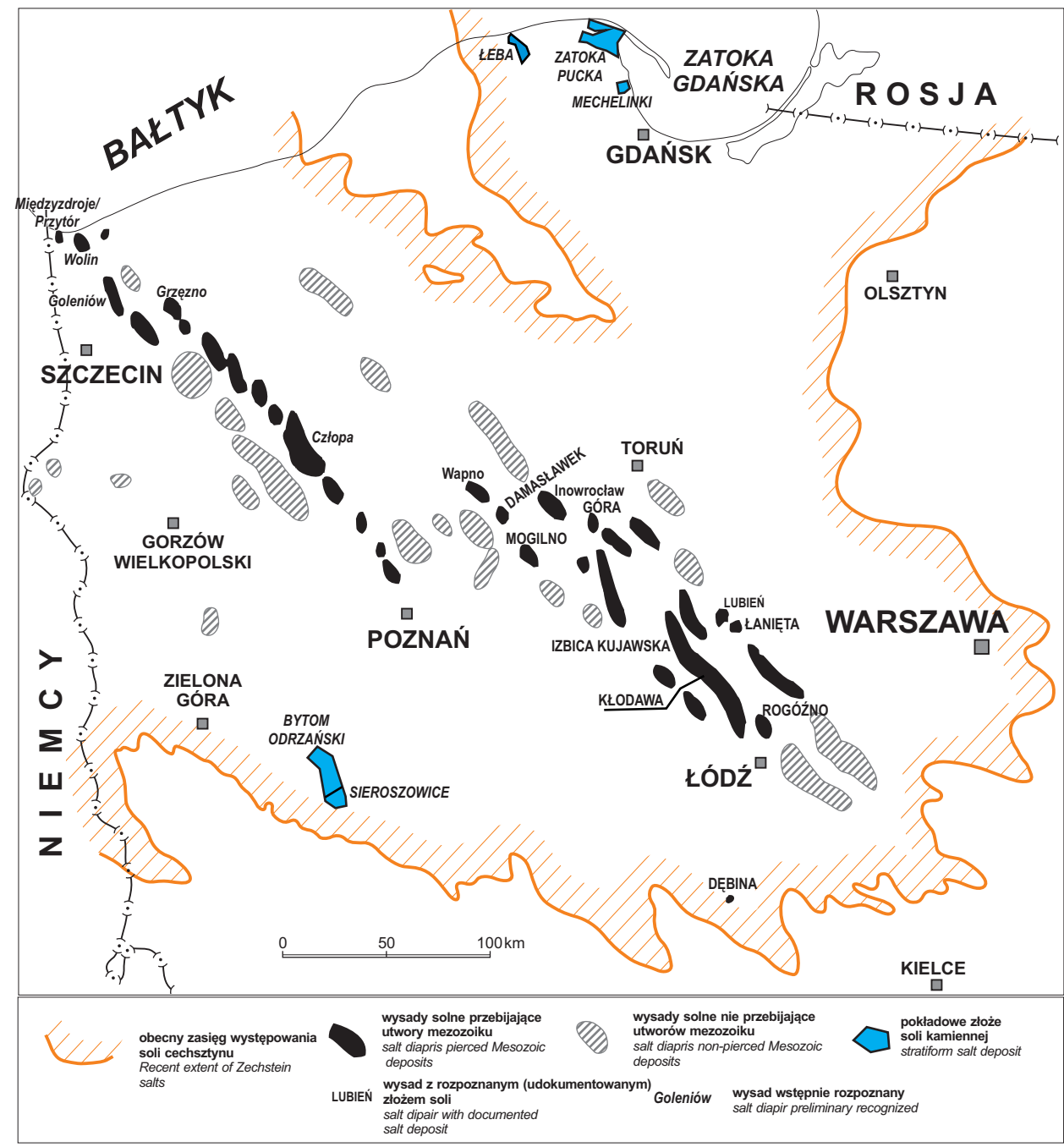

Fig. 4. Salt domes in Poland with predicted (prognostic and prospective) rock salt resources (after Czapowski \& Bukowski 2011)

Fig. 4. Wysady solne w Polsce z zasobami przewidywanymi soli kamiennej (wg Czapowski \& Bukowski 2011) 


\section{Table (Tabela) 4}

Selected parameters and predicted (prognostic and prospective) rock salt resources of documented and recognized salt domes in Poland (data after Bąk \& Przeniosło 1993)

Wybrane parametry $i$ zasoby przewidywane (prognostyczne + perspektywiczne) soli kamiennej $w$ wysadach solnych $w$ Polsce udokumentowanych $i$ rozpoznanych

\begin{tabular}{|c|c|c|c|c|c|c|c|}
\hline \multirow[b]{2}{*}{ No. } & \multirow{2}{*}{$\begin{array}{c}\text { Name of } \\
\text { salt dome } \\
\& \text { salt deposit }\end{array}$} & \multirow{2}{*}{$\begin{array}{c}\text { Deposit } \\
\text { area } \\
{\left[\mathrm{km}^{2}\right]}\end{array}$} & \multicolumn{2}{|c|}{ Resources } & \multirow{2}{*}{$\begin{array}{c}\text { Depth } \\
\text { of salt top } \\
{[\mathrm{m}]}\end{array}$} & \multirow{2}{*}{$\begin{array}{c}\text { Salt } \\
\text { thickness } \\
{[\mathrm{m}] \times} \\
\text { tectonic } \\
\text { coefficient }\end{array}$} & \multirow{2}{*}{$\begin{array}{c}\text { Main } \\
\text { component } \\
\text { content } \\
{[\% \mathrm{NaCl}]}\end{array}$} \\
\hline & & & $\begin{array}{c}\text { prognostic } \\
{[\text { mln t }]}\end{array}$ & $\begin{array}{c}\text { prospective } \\
{[\mathrm{mln} \mathrm{t}]}\end{array}$ & & & \\
\hline 1 & Mogilno (I+II) & 4.3 & 2710 & - & $1000-2000$ & $1000 \times 0.3$ & 95.6 \\
\hline 2 & Góra & 0.5 & 300 & - & $1000-2000$ & $1000 \times 0.3$ & $82-99$ \\
\hline 3 & Damasławek & 15.5 & 5860 & - & $1400-2000$ & $600 \times 0.3$ & 95.1 \\
\hline $4 a$ & $\begin{array}{c}\text { Kłodawa } \\
\text { (northern part) }\end{array}$ & 15.0 & - & 9250 & $1000-2000$ & $1000 \times 0.3$ & 97.5 \\
\hline $4 b$ & $\begin{array}{c}\text { Kłodawa } \\
\text { (middle part) }\end{array}$ & 14.9 & 9250 & - & $1000-2000$ & $1000 \times 0.3$ & 97.5 \\
\hline $4 c$ & $\begin{array}{c}\text { Kłodawa } \\
\text { (southern part) }\end{array}$ & 9.8 & - & 6000 & $1000-2000$ & $1000 \times 0.3$ & 97.5 \\
\hline 5 & Lubień & 3.5 & 2000 & - & $1000-2000$ & $1000 \times 0.3$ & 90.0 \\
\hline 6 & Eanięta & 8.5 & 5360 & - & $1000-2000$ & $1000 \times 0.3$ & 96.1 \\
\hline 7 & Rogóźno & 21.0 & 13000 & - & $1000-2000$ & $1000 \times 0.3$ & 97.5 \\
\hline \multirow{2}{*}{8} & \multirow{2}{*}{$\begin{array}{c}\text { Izbica } \\
\text { Kujawska }\end{array}$} & \multirow{2}{*}{4.0} & 1250 & - & $\leq 1000$ & $500 \times 0.3$ & b.d. \\
\hline & & & - & 2550 & $1000-2000$ & $1000 \times 0.3$ & b.d. \\
\hline \multirow{2}{*}{9} & \multirow{2}{*}{ Dębina } & \multirow{2}{*}{0.5} & 250 & - & $\leq 1000$ & $750 \times 0.3$ & $96.5-98$ \\
\hline & & & - & 300 & $1000-2000$ & $1000 \times 0.3$ & b.d. \\
\hline & Total & 97.5 & 39980 & 18100 & - & - & - \\
\hline
\end{tabular}

b.d. - lack of data.

The total area of predicted resources of listed domes is estimated at $97.5 \mathrm{~km}^{2}$, and their amount at over 58 bln $\mathrm{t}$, including the prognostic resources of $39.98 \mathrm{bln} \mathrm{t}$ and prospective resources of 18.1 bln t (Tab. 4).

Moreover, five preliminarily recognized salt structures were identified: Międzyzdroje-Przytór, Wolin, Goleniów, Grzęzno and Człopa (Fig. 4, Tab. 5) in which the depth of the salt mirror fulfils the assumed criteria for salt mining and construction of cavern storage facilities. The estimated volumes of these prospective resources were estimated after following 
elements: (a) surface area of the dome calculated from the tectonic map of the Zechstein-Mesozoic complex of the Polish Lowlands in the scale of 1:500 000 (Dadlez 1998), (b) the height of salt stock down to $2 \mathrm{~km}$, and (c) the coefficient of tectonic structural complication (0.3).

\section{Table (Tabela) 5}

Selected parameters and predicted (prognostic and prospective) rock salt resources of preliminary recognized salt domes in Poland (dome area data after Ślizowski et al. 2004)

Wybrane parametry $i$ zasoby przewidywane (prognostyczne + perspektywiczne) soli kamiennej $w$ wysadach solnych $w$ Polsce powierzchownie rozpoznanych (powierzchnie wysadów wg Slizowski et al. 2004)

\begin{tabular}{|c|c|c|c|c|c|c|}
\hline \multirow{2}{*}{ No. } & \multirow{2}{*}{$\begin{array}{c}\text { Name of } \\
\text { salt dome }\end{array}$} & $\begin{array}{c}\text { Dome } \\
\text { area* } \\
{\left[\mathrm{km}^{2}\right]}\end{array}$ & $\begin{array}{c}|c| \\
\text { prognostic } \\
{[\mathrm{mln} \mathrm{t}]}\end{array}$ & $\begin{array}{c}\text { prospective } \\
{[\mathrm{mln} \mathrm{t}]}\end{array}$ & $\begin{array}{c}\text { Depth of } \\
\text { salt top [m] }\end{array}$ & $\begin{array}{c}\text { Salt thickness } \\
{[\mathrm{m}] \times} \\
\text { tectonic } \\
\text { coefficient }\end{array}$ \\
\hline 1 & Międzyzdroje-Przytór & 3.9 & - & 1228 & $1000-2000$ & $500 \times 0.3$ \\
\hline 2 & Wolin & 10.6 & - & 4508 & $1000-2000$ & $675 \times 0.3$ \\
\hline 3 & Golenów & 7.0 & 538 & - & $\leq 1000$ & $122 \times 0.3$ \\
& Grzęzno & 4.1 & - & 4410 & $1000-2000$ & $1000 \times 0.3$ \\
\hline 4 & Człopa & 13.7 & - & 3711 & $1000-2000$ & $430 \times 0.3$ \\
\hline 5 & Total & 39.3 & 538 & 15324 & - & - \\
\hline
\end{tabular}

The predicted rock salt resources (prognostic and prospective ones) of those domes, with the total area of $39.3 \mathrm{~km}^{2}$, were estimated at 15.862 bln $\mathrm{t}$ (Tab. 5).

The total prognostic resources for Permian rock salt, calculated for 18 objects down to $2000 \mathrm{~m}$, were estimated at $192.46 \mathrm{bln} \mathrm{t}$, while the prospective ones at $2.062 \mathrm{bln} \mathrm{t}$. The predicted resources of stratiform deposits, with the total area of $19440.4 \mathrm{~km}^{2}$, were estimated at over 2180 bln t (prognostic resources: < 152 bln t, prospective resources: > 2028 bln t); the predicted resources of 14 domes were estimated at over 73.9 bln t (prognostic resources: 40.5 bln t, and prospective resources: 18.1 bln t).

For the Miocene rock salts three areas of predicted resources were identified in the Carpathian Foredeep (Fig. 5, Tab. 6).

The salt series with thickness $>35 \mathrm{~m}$ at the depth to $1000 \mathrm{~m}$, occurring between Wieliczka and Brzesko, were classified as the prognostic resources of ca. 1.3 bln t (Tab. 5). Salts found at the depth interval of 1000-1700 m between Brzesko and Tarnów represents the prognostic resources of over 1 bln $\mathrm{t}$ in the area of $48 \mathrm{~km}^{2}$. Two other deposits were identified between Tarnów and Pilzno: Pogórska Wola and Pilzno (Fig. 5, Tab. 6), with the total area of $5 \mathrm{~km}^{2}$ and the prognostic resources of $66 \mathrm{mln} \mathrm{t}$ (in Pogórska Wola) and the prospective resources of 44 mln t (Pilzno). 


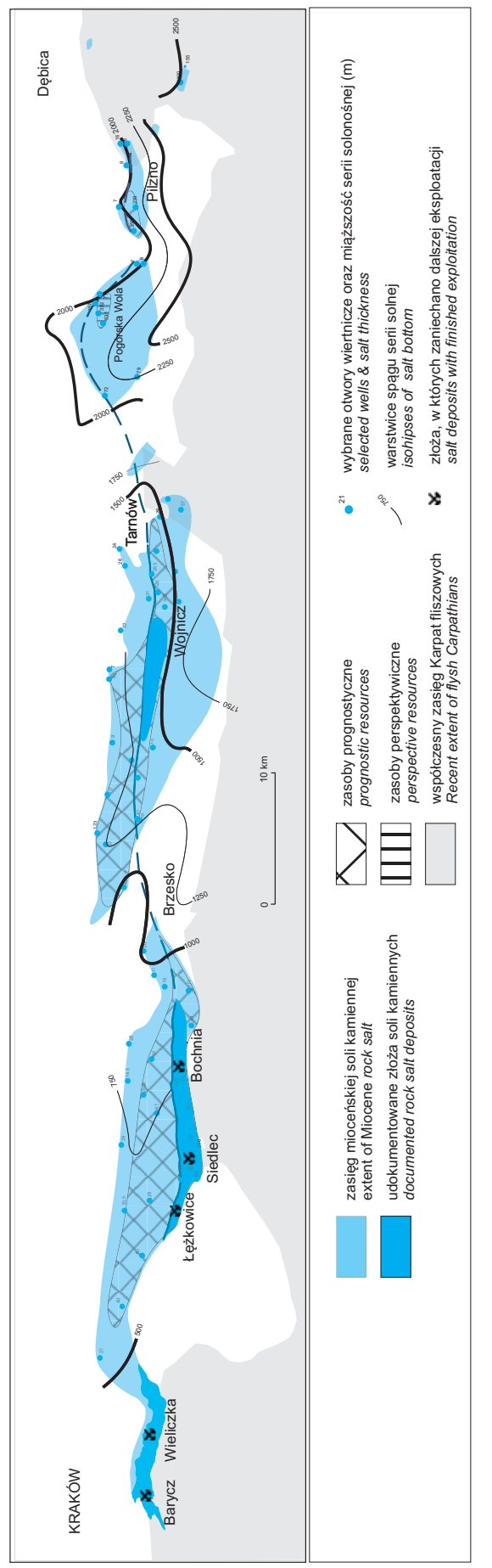

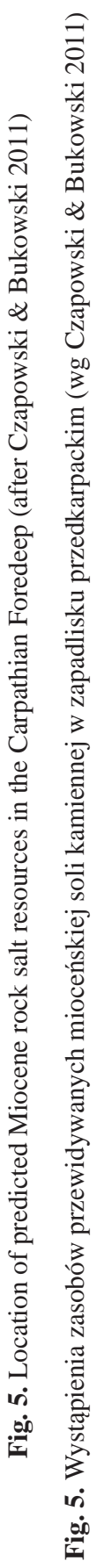




\section{Table (Tabela) 6}

Selected parameters and predicted (prognostic and prospective) Miocene rock salt resources in the Carpathian Foredeep

Wybrane parametry i zasoby przewidywane (prognostyczne + perspektywiczne) mioceńskiej soli kamiennej $w$ zapadlisku przedkarpackim

\begin{tabular}{|c|c|c|c|c|c|c|c|}
\hline \multirow[b]{2}{*}{ No. } & \multirow[b]{2}{*}{$\begin{array}{c}\text { Name } \\
\text { of deposit area }\end{array}$} & \multirow[b]{2}{*}{$\begin{array}{l}\text { Area } \\
{\left[\mathrm{km}^{2}\right]}\end{array}$} & \multicolumn{2}{|c|}{ Resources } & \multirow{2}{*}{$\begin{array}{c}\text { Depth } \\
\text { of salt top } \\
{[\mathrm{m}]}\end{array}$} & \multirow{2}{*}{$\begin{array}{c}\text { Salt } \\
\text { thickness } \\
{[\mathrm{m}] \times} \\
\text { tectonic } \\
\text { coefficient }\end{array}$} & \multirow{2}{*}{$\begin{array}{c}\text { Average } \\
\text { content of } \\
\text { main } \\
\text { component } \\
{[\% \mathrm{NaCl}]}\end{array}$} \\
\hline & & & $\begin{array}{c}\text { prognos- } \\
\text { tic } \\
{[\mathrm{mln} t]}\end{array}$ & $\begin{array}{c}\text { prospec- } \\
\text { tive } \\
{[\mathrm{mln} \mathrm{t}]}\end{array}$ & & & \\
\hline 1 & Wieliczka-Brzesko & 60.0 & 1323.0 & - & $\leq 1000$ & $35 \times 0.3$ & 80 \\
\hline 2 & Brzesko-Tarnów & 48.0 & 1058.0 & - & $\leq 1500$ & $35 \times 0.3$ & 80 \\
\hline \multirow[b]{2}{*}{3} & \multirow[b]{2}{*}{ Tarnów-Dębica } & $\begin{array}{c}3.0 \\
\text { (Pilzno } \\
\text { area) }\end{array}$ & 66.0 & - & $\leq 1500$ & $35 \times 0.3$ & 75 \\
\hline & & $\begin{array}{c}2.0 \\
\text { (Pogórska } \\
\text { Wola } \\
\text { area) }\end{array}$ & - & 44.0 & $1500-2000$ & $35 \times 0.3$ & 75 \\
\hline & Total & 115.0 & 2447.0 & 44.0 & - & - & - \\
\hline
\end{tabular}

\section{Comparison of predicted rock salt resources in Poland}

The total area of predicted Permian rock salt resources was estimated at 19,577.2 $\mathrm{km}^{2}$, including: the prognostic resources of over $192 \mathrm{bln} t$ and the prospective ones of ca. $2062 \mathrm{bln} t$ (Tab. 7). The total predicted resources of those salts were estimated at over $2254 \mathrm{bln} \mathrm{t}$, of which over $96.7 \%$ are the resources found in stratiform deposits (Fig. 6).

The total area of prognostic resources of Permian salt stratiform deposits was estimated at $19440.4 \mathrm{~km}^{2}$, while the area of prospective resources at $17500 \mathrm{~km}^{2}$, of which a larger proportion constituted the salt bodies from the Peri-Baltic Syneclise. The predicted resources of stratiform deposits were estimated at over $2108 \mathrm{bln} \mathrm{t}$, including the prognostic resources of less than 152 bln t (mainly in the the Leba Elevation area), while the prospective ones of over 2028 bln t (mostly in the Peri-Baltic Syneclise and the Fore-Sudetic Monocline).

The predicted rock salt resources found in salt domes (14 structures) were estimated at ca. 74 bln t (3.3\% of total Permian rock salt resources) (Fig. 6) and the area of $136.8 \mathrm{~km}^{2}$, including the prognostic resources constituting more than 40 bln $\mathrm{t}$ and the prospective ones of over 33 bln t (Tab. 7). 


\section{Table (Tabela) 7}

Area and predicted (prognostic and prospective) Miocene and Permian rock salt resources in Poland

Powierzchnia i zasoby przewidywane (prognostyczne + perspektywiczne) mioceńskiej i permskiej soli kamiennej w Polsce

\begin{tabular}{|c|c|c|c|c|}
\hline \multirow{2}{*}{$\begin{array}{l}\text { Type of salt } \\
\text { occurrences }\end{array}$} & \multirow{2}{*}{$\begin{array}{c}\text { Area } \\
{\left[\mathrm{km}^{2}\right]}\end{array}$} & \multicolumn{2}{|c|}{ Resources ( $\%$ of total data) } & \multirow{2}{*}{$\begin{array}{c}\text { Total resource } \\
\text { volume } \\
{[\mathrm{mln} \mathrm{t}]}\end{array}$} \\
\hline & & $\begin{array}{l}\text { prognostic } \\
{[\mathrm{mln} \mathrm{t}]}\end{array}$ & $\begin{array}{l}\text { prospective } \\
{[\mathrm{mln} \mathrm{t}]}\end{array}$ & \\
\hline \multicolumn{5}{|c|}{ PERMIAN SALTS } \\
\hline Stratiform & 19440.4 & $\begin{array}{c}151938.7 \\
(6.7 \%)\end{array}$ & $\begin{array}{c}2028332.0 \\
(90.0 \%)\end{array}$ & $\begin{array}{c}2108270 \\
(96.7 \%)\end{array}$ \\
\hline Salt domes & 136.8 & $\begin{array}{c}40518.0 \\
(1.8 \%)\end{array}$ & $\begin{array}{c}33424.0 \\
(1.5 \%)\end{array}$ & $\begin{array}{c}73942.0 \\
(3.3 \%)\end{array}$ \\
\hline Total & 19577.2 & $\begin{array}{c}192456.7 \\
(8.5 \%)\end{array}$ & $\begin{array}{c}2061756.0 \\
(91.5 \%)\end{array}$ & $\begin{array}{l}2254212.7 \\
\quad(100 \%)\end{array}$ \\
\hline \multicolumn{5}{|c|}{ MIOCENE SALTS } \\
\hline Total & 115.0 & 2447.0 & 44.0 & 2491.0 \\
\hline $\begin{array}{l}\text { Total data of predicted } \\
\text { salt rock resources }\end{array}$ & 19692.2 & 194903.7 & 2061800 & 2256703.7 \\
\hline
\end{tabular}

The total area of predicted Miocene rock salt resources was estimated at $115 \mathrm{~km}^{2}$, with their prognostic resources of $2.4 \mathrm{bln} t$ and the prospective ones of $44 \mathrm{mln} t$ (Tab. 7). Those resources are of marginal importance because they constitute only $0.1 \%$ of total predicted rock salt resources in Poland.

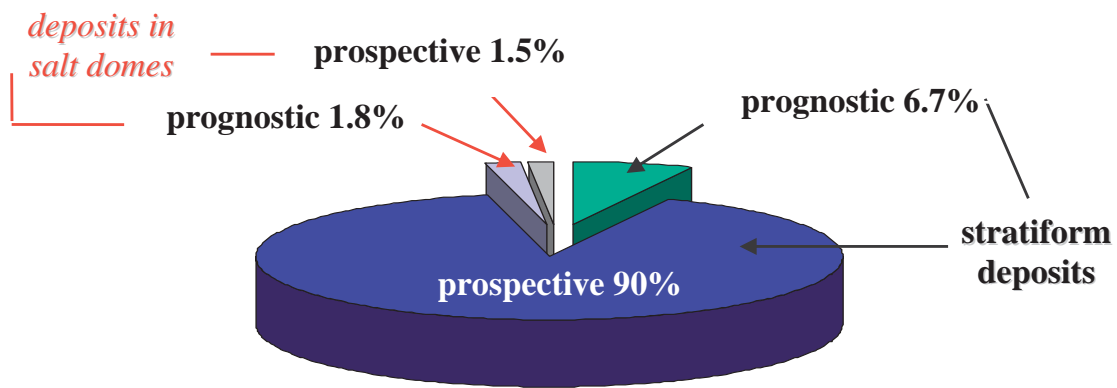

Fig. 6. Relation diagramme of predicted resources of various types of Permian rock salt deposits in Poland

Fig. 6. Relacje typów wystąpień i przewidywanych zasobów permskich soli kamiennych w Polsce 


\section{Potash salt}

The anticipated economic resources (597 mln t) (Szuflicki et al. 2011) of four potashmagnesium salts deposits of polyhalite type, documented in $\mathrm{C}_{2}$ category, found in the Puck Bay area (Figs 2-3), were included in the prognostic resources (Tab. 8) due to a relatively low recognition (low documenting category), the depth of occurrence to $1,000 \mathrm{~m}$, lack of management and the fundamental change of concept of polyhalite mineralization genesis, crucially affected the resource estimation.

In the Polish Lowlands, the concentrations of potash and potash-magnesium salts are associated with the following lithostratigraphic units: Older Potash (K2) and Younger Potash (K3). They were recognized in the salt domes in Inowrocław, Góra, Mogilno and Kłodawa. Only in the Kłodawa dome (Fig. 3) these salts have been documented (e.g. Werner 1962) as the so-called industrial economic resources within the Younger Potash (K3) unit. The prognostic resources of those salts found in the central part of Kłodawa dome were estimated at $100 \mathrm{mln} t$ (Bąk \& Przeniosło 1993). Their regular exploitation is not realized because of difficult geological conditions (varied thickness and content of useful components).

In the Fore-Sudetic Monocline area (Fig. 3), the potash-magnesium stratiform occurrences located within the evaporates of cycles PZ2 and PZ3 have been described since the 1960's, but they resources have not been documented yet (Czapowski \& Bukowski 2010, with literature). Their recognition status has not changed essentially since 1993. Consequently, the previous estimations (Bąk \& Przeniosło 1993) of the prospective resources (volume of ca. $300 \mathrm{mln}$ tons and the area of ca. $100 \mathrm{~km}^{2}$ ) were cited (Tab. 8).

The total area of predicted Permian potash-magnesium salts resources was estimated at $117.76 \mathrm{~km}^{2}$, with the prognostic resources of over $719 \mathrm{mln} \mathrm{t}$ and the prospective ones of $300 \mathrm{mln} \mathrm{t}$ (Tab. 8). The total predicted resources of those salts in Poland are up to $1.02 \mathrm{bln} \mathrm{t}$, of which $70.6 \%$ constitute the prognostic resources of polyhalite type in the Puck Bay area. The remaining quantities constitute mainly the prospective resources of the Zielona Góra-Nowa Sól areas and of the Fore-Sudetic Monocline. The documented but not exploited resources of the Kłodawa dome are not essential (9.8\% of total resources).

\section{CONCLUSIONS}

The anticipated economic rock salt resources, documented in 19 deposits, amounted to nearly 20.7 bln t in 2010, but the anticipated subeconomic ones -85.3 bln t. The Miocene salt resources of over 4.36 bln t constitute only $5.1 \%$ of the Polish anticipated economic rock salt resources, with the domination of Permian salts ( $81 \mathrm{bln} t)$, including resources in the domes (65.6\% of national resources), while the resources of stratiform deposits were estimated at nearly 25 bln $t$ ( $29.3 \%$ of national resources). The anticipated subeconomic resources became calculated at over 20.6 bln t, with absolute domination of the Permian salts (20.6 bln t; $99.72 \%$ of the total national subeconomic resources), concentrated mainly in salt domes (ca. 13 bln t; $62.6 \%$ of total resources), while the resources of stratiform deposits constituted only 7.7 bln t (37.4\%). The anticipated subeconomic resources of the Miocene rock salt were marginal (58.2 $\mathrm{mln} \mathrm{t}$; $0.28 \%$ of total resources). 


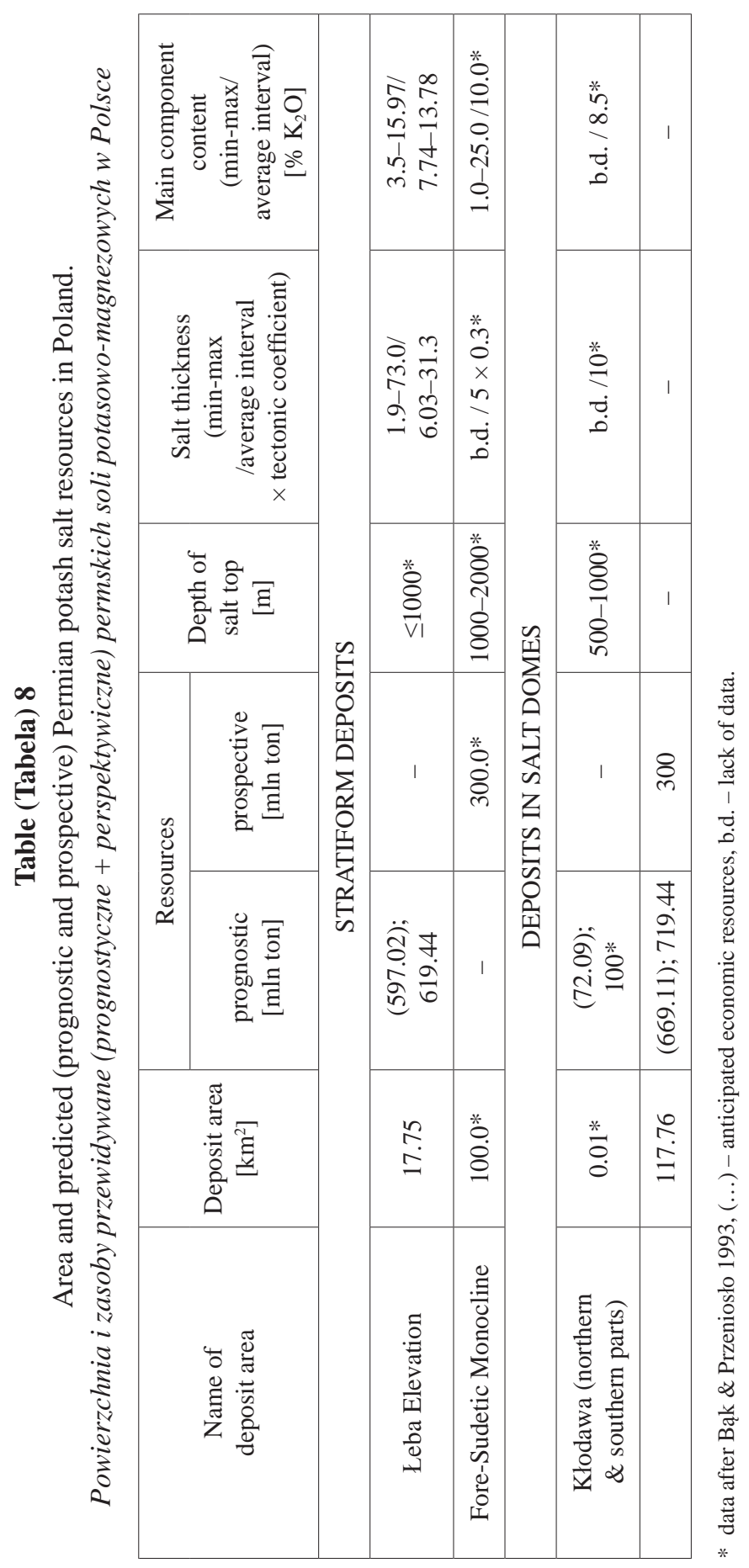


The estimated predicted (prognostic and prospective) rock salt resources in Poland are over 2256 bln t, including the Permian salts of over 2254 bln t (96.7\% of them belonged to the stratiform deposits, with the remaining proportion of resources located in the salt domes). The predicted resources of Miocene rock salts were estimated at $2.45 \mathrm{bln}$ t. They are of minor importance, as well as the related documented resources $(0.1 \%$ of the national predicted resources).

The total rock salt resources in Poland were estimated at nearly 2358.3 bln t at the beginning of the 21 st century (Tab. 9), of which the absolute majority ( $87.4 \%$ ) constituted the prospective Permian salt resources (Fig. 7), situated mainly in stratiform deposits. The documented resources represent only $4.3 \%$ of the total national rock salt resource base.

Table (Tabela) 9

Total volume of rock salt resources in Poland in 2010

Stan zasobów soli kamiennej w Polsce w 2010 roku

\begin{tabular}{|c|c|}
\hline \multicolumn{2}{|c|}{ Resources documented [mln t] (\% of total) } \\
\hline anticipated economic & $80956.0(3.4 \%)$ \\
\hline anticipated subeconomic & $20643.1(0.9 \%)$ \\
\hline \multicolumn{2}{|c|}{ Predicted resources [mln t] (\% of total) } \\
\hline prognostic & $194903.7(8.3 \%)$ \\
\hline propspective & $2061800.0(87.4 \%)$ \\
\hline Total & $2358311.8(100 \%)$ \\
\hline
\end{tabular}

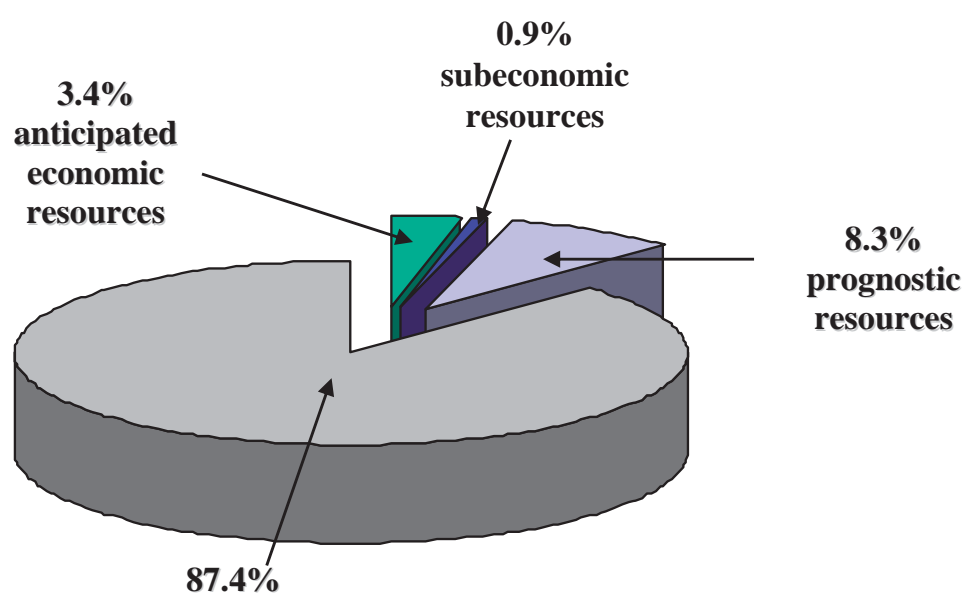

Fig. 7. Relation diagramme of various types of rock salt resources in Poland

Fig. 7. Diagram pokazujący proporcje między zasobami soli kamiennych w Polsce 
The documented (anticipated economic and subeconomic) rock salt resources would be adequate for more than 26000 years of total exploitation, assuming that the annual salt production equalled ca. $3.9 \mathrm{mln}$ tons in the last five years (2006-2010; with annual changes from $3.2 \mathrm{mln}-4.4 \mathrm{mln} \mathrm{t}$ ). With the similar assumptions, the predicted rock salt resources would be adequate for more than 500 years of production if only $1 / 10^{6}$ portion of them is received.

The anticipated economic resources of Permian potash-magnesium salts constitute small quantities, represented (after a new estimation - $72 \mathrm{mln}$ ) by the deposit in the Kłodawa salt dome.

The calculated prognostic potash-magnesium salt resources (to the depth of $1000 \mathrm{~m}$ ) were estimated at $719.44 \mathrm{mln}$ t. They included the salts of sulphate type (polyhalite), occurred in the Puck Bay area (619.44 mln t, together with the resources being previously considered as the anticipated economic ones and equalled $597 \mathrm{mln} \mathrm{t}$ ), and the resources in Kłodawa dome $(100 \mathrm{mln} \mathrm{t})$. The prospective resources of those salts located on the ForeSudetic Monocline (at the depth interval of 1000-2000 m) were estimated at $300 \mathrm{mln}$ t. The total predicted potash-magnesium salt resources were estimated at nearly $1.02 \mathrm{bln} t$ in Poland but their exploitation is presently not economically profitable.

\section{REFERENCES}

Bąk B. \& Przeniosło S. (red.), 1993. Zasoby perspektywiczne kopalin Polski wg stanu na 31 XII $1990 r$. PIG, Warszawa.

Czapowski G. \& Bukowski K., 2010. Geology and resources of salt deposits in Poland: the state of the art. Geological Quarterly, 54, 4, 509-518.

Czapowski G. \& Bukowski K., 2011. Sól kamienna i sole potasowo-magnezowe. In: Wołkowicz S., Smakowski T. \& Speczik S. (red.), Bilans perspektywicznych zasobów kopalin Polski wg stanu na 31 XII 2009 r., PIG-PIB, Warszawa, 134-142.

Czapowski G., Tomassi-Morawiec H., Chełmiński J. \& Tomaszczyk M., 2008. Stopień rozpoznania i perspektywy zagospodarowania cechsztyńskich złóż soli w rejonie Zatoki Gdańskiej. Górnictwo Odkrywkowe, XLX/II, 2-3, 47-55.

Karnkowski P.H. \& Czapowski G., 2007. Underground hydrocarbons storages in Poland: actual investments and prospects. Przeglad Geologiczny, 55, 12/1, 1068-1074.

Kozula R. \& Golczak A., 1988. Dokumentacja geologiczna złoża rud miedzi „Bytom Odrzański” w kat. C1 i C2. CAG PIG, Warszawa.

Szuflicki M., Malon A. \& Tymiński M. (red.), 2011. Bilans zasobów kopalin i wód podziemnych Polsce wg stanu na 31 XII 2010 r. PIG-PIB, Warszawa.

Ślizowski J., Lankof L. \& Wojtuszewska K., 2007. Geomechaniczna ocena optymalnej głębokości komór magazynowych gazu ziemnego w polskich złożach soli kamiennej. WUG, Bezpieczeństwo Pracy i Ochrona Środowiska w Górnictwie, 6 (154), 50-61.

Werner Z., 1962. Dokumentacja geologiczna złoża soli potasowo-magnezowych i soli kamiennej w kłodawskim wysadzie solnym. CAG PIG, Warszawa. 


\section{Streszczenie}

Udokumentowane w 19 złożach zasoby bilansowe soli kamiennej wynosiły w 2010 roku 85.3 mld t, zaś pozabilansowe - blisko 20.7 mld t (Tab. 1, Fig.1). Zasoby złóż soli mioceńskich - ponad 4.36 mld t - stanowią jedynie 5.1\% krajowych bilansowych zasobów soli kamiennej, przeważają zasoby soli permskich $(81 \mathrm{mld}$ t), wśród których dominują $(65.6 \%$ zasobów krajowych) zasoby w wysadach solnych, zasoby soli ze złóż pokładowych oceniane są na blisko 25 mld t (29.3\% zasobów krajowych) (Fig. 1). Z kolei zasoby pozabilansowe wynosiły ponad 20.6 mld t, z absolutną przewagą zasobów soli permskich (20.6 mld t; $99.72 \%$ całości krajowych zasobów pozabilansowych), skupionych głównie w wysadach solnych (ok. 13 mld t; 62.6\% całości zasobów), zaś zasoby złóż pokładowych to jedynie 7.7 mld t (37.4\%). Zasoby pozabilansowe mioceńskiej soli kamiennej to margines (58.2 $\mathrm{mln}$ t; $0.28 \%$ całości zasobów).

Oszacowane przewidywane (prognostyczne i perspektywiczne - Tab. 2, Fig. 3) zasoby soli kamiennej w Polsce wynoszą ponad 2256 mld t, w tym zasoby soli permskiej to ponad 2254 mld t, z czego ponad $96.7 \%$ stanowią zasoby wystąpień pokładowych soli (Tab. 3), pozostałą część tworzą zasoby w wysadach solnych (Tab. 4, 5, Fig. 4, 6). Zasoby przewidywane mioceńskiej soli kamiennej (Fig. 5), ocenione na $2.45 \mathrm{mld}$ t (Tab. 6), mają - podobnie jak jej zasoby udokumentowane - znaczenie marginalne $(0.1 \%$ krajowych zasobów przewidywanych) (Tab. 7).

Łączny stan zasobów soli kamiennej w Polsce na początku XXI wieku szacowany jest na blisko 2358 mld t (Tab. 9), z czego absolutną większość (87.4\% całości) stanowią zasoby perspektywiczne (Fig. 7) soli permskiej, ulokowane głównie w wystąpieniach pokładowych. Zasoby dotychczas udokumentowane to jedynie $4.3 \%$ całego krajowego potencjału zasobowego soli kamiennej (Tab. 9, Fig. 7).

Udokumentowane (bilansowe i pozabilansowe) zasoby soli kamiennej wystarcza na ponad 26 tys. lat wydobycia, jeśli przyjmiemy średnie roczne wydobycie w Polsce w ciągu ostatnich pięciu lat (2006-2010, zmiany rocznego wydobycia od $3.2 \mathrm{mln}$ t do $4.4 \mathrm{mln}$ t) wynoszące ok. $3.9 \mathrm{mln}$. Przy podobnym założeniu zasoby przewidywane soli kamiennej starczą na ponad 500 lat wydobycia, zakładając pozyskanie jedynie $1 / 10^{6}$ części tych zasobów.

W świetle nowej oceny zasoby bilansowe soli potasowo-magnezowych stanowią jedynie niewielką ilość (72 mln t), która zostałą udokumentowana w wysadzie solnym Kłodawa (Fig. 3). Obliczone zasoby prognostyczne soli potasowo-magnezowych (do głębokości 1000 m) (Tab. 8) wynoszą 719.44 mln t. Obejmują one zasoby złóż soli typu siarczanowego (polihalit), występujące w rejonie Zatoki Puckiej (Fig. 2) (619.44 mln t, w tym zasoby dotychczas uznawane za bilansowe - $597 \mathrm{mln}$ t) oraz zasoby w obrębie wysadu kłodawskiego (100 mln t). Zasoby perspektywiczne tych soli na terenie monokliny przedsudeckiej (w przedziale głębokości 1-2 km) oszacowano na $300 \mathrm{mln}$ t (Tab. 8). Łączne zasoby przewidywane soli potasowo-magnezowych w Polsce oszacowano na blisko $1.02 \mathrm{mld} \mathrm{t}$. Eksploatacja tych soli nie jest obecnie opłacalna. 